\title{
Formulation and Evaluation of Fast Dissolving Tablets of Prochlorperazine Dimaleate
}

\author{
Kavita Varma Shukla, Vishal Sharma * \\ Shri Ram Institute of Pharmacy, Madhotal, Jabalpur, Madhya Pradesh, 482002, India
}

\begin{abstract}
Prochlorperazine dimaleate (also known as Prochlorperazin, Compazine, Capazine, Stemetil, PCZ), the dimaleate salt of Prochlorperazine, is a dopamine $\left(D_{2}\right)$ receptor antagonist that belongs to the phenothiazine class of antipsychotic agents that are used for the antiemetic treatment of nausea and vertigo. It is also a highly potent typical antipsychotic, 10-20 times more potent than chlorpromazine. Prochlorperazine dimaleate is also used to treat migraine headaches. The concept of formulating fast dissolving tablets containing PCZ offers a suitable and practical approach in serving desired objective of faster disintegration and dissolution characteristics with increased bioavailability. Fast dissolving tablets of PCZ were prepared by direct compression methods and blend was evaluated for the pre-compression parameters such as bulk density, compressibility, angle of repose etc. The tablets were prepared by using crosscarmellose sodium, crospovidone and so dium starch glycolate, as super disintegrants in different concentration along with microcrystalline cellulose. Total six formulations were prepared and evaluated for hardness, friability, weight variation, content uniformity, wetting time, water absorption ratio, disintegration time and invitro drug release. In-vitro dissolution studies are performed by using 6.8PH buffer at 50 rpm by paddle method. Overall, the formulation F5containing of CP was found to be promising and has shown a disintegration time 65 sec. The stability studies were performed for two months (accelerated studies) as per ICH guidelines. The optimized formulation (F5) showed no significant variations for the tablets parameters and it was stable for the specified time period. Thus results conclusively demonstrated successful masking of taste and fastest disintegration of the formulated tablets in oral cavity.
\end{abstract}

Keywords: Fast dissolving tablets, Prochlorperazine dimaleate, Superdisintegrants, Pre-compression

Article Info: Received 08 June 2019; Review Completed 28 July 2019; $\quad$ Accepted 06 Aug 2019; Available online 15 August 2019

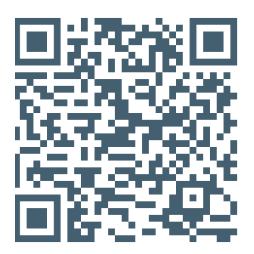

Cite this article as:

Shukla KV, Sharma V, Formulation and Evaluation of Fast Dissolving Tablets of Prochlorperazine Dimaleate, Journal of Drug Delivery and Therapeutics. 2019; 9(4-s):457-461 http://dx.doi.org/10.22270/jddt.v9i4-s.3355

*Address for Correspondence:

Vishal Sharma, Shri Ram Institute of Pharmacy, Madhotal, Jabalpur, Madhya Pradesh, 482002, India

\section{INTRODUCTION}

Many patients find it difficult to swallow tablets and hard gelatin capsules and thus do not comply with prescription, which results in high incidence of non-compliance and ineffective therapy. It is estimated that $70 \%$ of the population is affected by this problem [1]. Recent advances in novel drug delivery systems (NDDS) aimed to enhance safety and efficacy of drug molecule by formulating a convenient dosage form for administration and to achieve better patient compliance. One such approach is fast dissolving tablets (FDT) [1-4]. PCZ is a phenothiazine antipsychotic and widely used in prevention and treatment of nausea, vomiting including that associated with migraine or drug-induced emesis [5]. The concept of formulating fast dissolving tablets containing PCZ offers a suitable and practical approach in serving desired objective of faster disintegration and dissolution characteristics with increased bioavailability by simple and cost effective direct compression technique. Upon ingestion, the saliva serves to rapidly disperse/dissolve the dosage form. The saliva containing the dissolved/dispersed medicament is then swallowed and the drug is absorbed in the normal way. Some drugs are absorbed from mouth, pharynx and esophagus as the saliva passes down into the stomach [6]. In such cases, bioavailability is significantly greater than those observed from conventional dosage form. In present study an attempt has been made to formulate the orally disintegrating tablets by direct compression method using sodium starch glycolate, crosscarmellose sodium and crospovidone as the superdisintegrants for rapid dissolution of drug and absorption, which may produce the rapid onset of action.

\section{MATERIALS AND METHODS}

\section{Materials}

Prochlorperazine dimaleate was purchased from Sigma Aldrich-Merck, Bengaluru, Karnataka, India. Crospovidone, sodium starch glycolate and sodium starch glycolate was obtained from Hi-Media Laboratories Pvt. Ltd., Mumbai, 
India. Micro crystalline cellulose, mannitol, talc and magnesium stearate was procured from Central Drug House (P) Ltd. New Delhi. All other solvents and chemicals used were of analytical grade.

\section{Methods}

\section{Preformulation studies}

\section{Standardization of PCZ by UV-Visible spectrophotometry}

Accurately weighed $10 \mathrm{mg}$ of drug was dissolved in $10 \mathrm{ml}$ of phosphate buffer $\mathrm{pH} 6.8$ solutions in $10 \mathrm{ml}$ of volumetric flask. The resulted solution $1000 \mu \mathrm{g} / \mathrm{ml}$ and from this solution $1 \mathrm{ml}$ pipette out and transfer into $10 \mathrm{ml}$ volumetric flask and volume make up with phosphate buffer $\mathrm{pH} 6.8$ solution prepare suitable dilution to make it to a concentration range of $2-10 \mu \mathrm{g} / \mathrm{ml}$. The spectrum of this solution was run in $200-400 \mathrm{~nm}$ range in U.V. spectrophotometer (Labindia-3000+).

\section{Drug-excipient compatibility study}

FTIR spectra of pure drugs, polymers used and blends were recorded on $\mathrm{KBr}$ disk method using Brukers Alpha Spectrophotometer with IR solution software to confirm the compatibility between drug and excipients. Sample powder was thoroughly mixed by triturating with potassium bromide in a glass mortar with pestle and compressed into disks in a hydraulic press (Techno search Instruments, India). FTIR spectra of all the samples were recorded over a spectral region from 4700 to $400 \mathrm{~cm}-1$ using 20 scans with 4 $\mathrm{cm}-1$ resolution.

\section{Preparation of tablets of PCZ}

Fast dissolving tablets of PCZ were prepared by direct compression [7] according to the formulae given in Table 1. All the ingredients were passed through \# 60 mesh separately. Then the ingredients were weighed and mixed in geometrical order and compressed into tablets of $150 \mathrm{mg}$ using $8 \mathrm{~mm}$ round flat punches on 10-station rotary tablet machine.

Table 1 Composition of PCZ fast dissolving tablets

\begin{tabular}{|c|c|c|c|c|c|c|}
\hline \multirow{2}{*}{ Ingredients (mg) } & \multicolumn{7}{|c|}{ Formulation code } \\
\cline { 2 - 7 } & F1 & F2 & F3 & F4 & F5 & F6 \\
\hline $\begin{array}{c}\text { Prochlorperazine } \\
\text { dimaleate }\end{array}$ & 25 & 25 & 25 & 25 & 25 & 25 \\
\hline Sodium Starch glycolate & 10 & 20 & - & - & - & - \\
\hline Croscarmellose sodium & - & - & 10 & 20 & - & - \\
\hline Crospovidone & - & - & - & - & 10 & 20 \\
\hline Mannitol & 10 & 10 & 10 & 10 & 10 & 10 \\
\hline $\begin{array}{c}\text { Microcrystalline } \\
\text { cellulose }\end{array}$ & 94 & 84 & 94 & 84 & 94 & 84 \\
\hline Talc & 5 & 5 & 5 & 5 & 5 & 5 \\
\hline Magnesium stearate & 6 & 6 & 6 & 6 & 6 & 6 \\
\hline Total weight & 150 & 150 & 150 & 150 & 150 & 150 \\
\hline
\end{tabular}

\section{Evaluation of fast dissolving tablets of PCZ}

\section{Precompression parameters}

\section{Angle of repose ( $\theta)$}

The frictional forces in a loose powder or granules can be measured by the angle of repose. This is the maximum angle possible between the surface of a pile of powder or granules and the horizontal plane.

$$
\begin{gathered}
\operatorname{Tan} \theta=h / r \\
\theta=\tan -1(h / r)
\end{gathered}
$$

Where, $\theta$ is the angle of repose, $h$ is the height, $r$ is the radius.

The granules were allowed to flow through the funnel fixed to a stand at definite height. The angle of repose was then calculated by measuring the height and radius of the heap of granules formed.

\section{Bulk density}

Both loose bulk density (LBD) and tapped bulk density (TBD) were determined. Accurately weighed amount of granules taken in a $50 \mathrm{ml}$ capacity measuring cylinder was tapped for 100 times on a plane hard wooden surface and estimated the LBD and TBD, calculated by using following formulas.

LBD (Loose Bulk Density) = Mass of Powder/Volume of Packing

\section{TBD (Tapped Bulk Density) = Mass of Powder/Tapped Volume of Packing}

\section{Compressibility index}

The compressibility index of the granules was determined by Carr's compressibility index.

$$
\text { Carr's index }(\%)=[(\mathrm{TBD}-\mathrm{LBD}) / \mathrm{TBD}] \times 100 \text {. }
$$

\section{Hausner's ratio}

Hausner's ratio is an indirect index of ease of measuring the powder flow. It was calculated by the following formula [8].

$$
\text { Hausner's ratio }=\text { Tapped density } / \text { Bulk density. }
$$

\section{Evaluation of Tablets}

\section{Thickness}

Twenty tablets from the representative sample were randomly taken and individual tablet thickness was measured by using digital vernier caliper [9].

\section{Hardness}

Tablet hardness was measured by using Monsanto hardness tester. From each batch six tablets were measured for the hardness and average of six values was noted along with standard deviations.

\section{Friability Test}

From each batch, ten tablets were accurately weighed and placed in the friability test apparatus (Roche friabilator). 
Apparatus was operated at $25 \mathrm{rpm}$ for 4 minutes and tablets were observed while rotating. The tablets were then taken after 100 rotations, de dusted and reweighed. The friability was calculated as the percentage weight loss.

$\%$ friability was calculated as follows

$$
\% \text { Friability }=(\mathrm{W} 1-\mathrm{W} 2) \times 100 / \mathrm{W} 1
$$

Where $\mathrm{W} 1=$ Initial weight of the 10 tablets, $\mathrm{W} 2=$ Final weight of the 10 tablets after testing.

Friability values below $0.5-1 \%$ are generally acceptable.

\section{Weight Variation Test}

To study weight variation individual weights (WI) of 20 tablets from each formulation were noted using electronic balance. Their average weight (WA) was calculated. Percent weight variation was calculated as follows. Average weights of the tablets along with standard deviation values were calculated.

\section{Drug content}

The test is mandatory for tablets with $10 \mathrm{mg}$ or less weight of active ingredient. Ten randomly selected tablets from each formulation (F1 to F6) were finely powdered and Drug equivalent to $10 \mathrm{mg}$ of drug dissolved in $10 \mathrm{ml}$ phosphate buffer pH 6.8 sonicate it for 20 minutes, till the entire drug leached out from complex, then the solution was filtered through whatman filter paper No. 41. From this solution take $1 \mathrm{ml}$ and diluted up to $100 \mathrm{ml}$ with phosphate buffer $\mathrm{pH}$ 6.8 and the drug content was determined spectrophotometrically at $256 \mathrm{~nm}$.

\section{In vitro disintegration time}

The disintegration test was performed using an USP disintegration apparatus, with distilled water at $24 \pm 0.50 \mathrm{C}$. The time reported to obtain complete disintegration of six tablets were recorded and average was reported.

\section{Dissolution rate studies}

The prepared tablets were evaluated for in vitro drug release. The drug release studies were carried out using USP XXII paddle type Dissolution test apparatus. A tablet placed in dissolution media $(900 \mathrm{ml})$ which was stirred at $75 \mathrm{rpm}$ maintained at $37 \pm 0.2^{\circ} \mathrm{C}$. Samples were withdrawn at different time interval and compensated with same amount of fresh dissolution medium. Volume of sample withdrawn was made up to $10 \mathrm{ml}$ Phosphate buffer $\mathrm{pH}$ 6.8. The samples withdrawn were assayed spectrophotometrically at 256.0 $\mathrm{nm}$ using UV visible spectrophotometer. The release of drug was calculated with the help of standard curve of PCZ [10, 11].

\section{RESULTS AND DISCUSSION}

Solubility of PCZ was freely soluble in methanol, sparingly soluble in chloroform, soluble in water, $0.1 \mathrm{~N} \mathrm{HCL}, 0.1 \mathrm{~N}$ $\mathrm{NaOH}$ and $6.8 \mathrm{pH}$ phosphate buffers. The $\lambda$ max of PCZ was found to be $256 \mathrm{~nm}$ by using U.V. spectrophotometer (Labindia-3000+) in linearity range $2-10 \mu \mathrm{g} / \mathrm{ml}$ Fig. $1 \& 2$ Tablet powder blend was subjected to various precompression parameters Table 2 . The angle of repose values indicates that the powder blend has good flow properties. The bulk density, tapped density, compressibility index and
Hauser's ratio of all the formulations was found to be within the range and showing that the powder has well flow properties. The results of post-compression parameters such as the uniformity of weight, hardness, thickness, friability and drug content of the tablets are given in Table 3. All the tablets of different batches complied with the official requirements of uniformity of weight. The hardness of the tablets ranged from $3.4 \pm 0.2$ to $3.6 \pm 0.2 \mathrm{~kg} / \mathrm{cm}^{2}$ and the friability values were less than $0.9 \%$ indicating that the tablets were compact and hard. The thickness of the tablets ranged from 2.2 to $2.5 \mathrm{~mm}$. All the formulations satisfied the content of the drug as they contained 99.12 to $99.85 \%$ of PCZ and good uniformity in drug content was observed. Thus all the physical attributes of the prepared tablets were found be practically within control. The result in vitro disintegration were within the prescribe limit and comply with the criteria for orally disintegrating tablets. The tablets were evaluated for in vitro dissolution studies in phosphate buffer $\mathrm{pH} 6.8$ for $10 \mathrm{~min}$. The results of the optimized formulation F5 showed maximum drug release i.e. $98.89 \%$ at the end of $10 \mathrm{~min}$. The results of release studies of formulations $\mathrm{F} 5$ was shown in Table 4. The in vitro drug release data of the optimized formulation F5 was subjected to goodness of fit test by linear regression analysis according to zero order, first order kinetic equation, Higuchi's and Korsmeyer's models in order to determine the mechanism of drug release. When the regression coefficient values of were compared, it was observed that ' $r$ ' values of first order was maximum i.e. 1.000 hence indicating drug release from formulations was found to follow first order kinetics Table 5 \& Fig. 3-6.

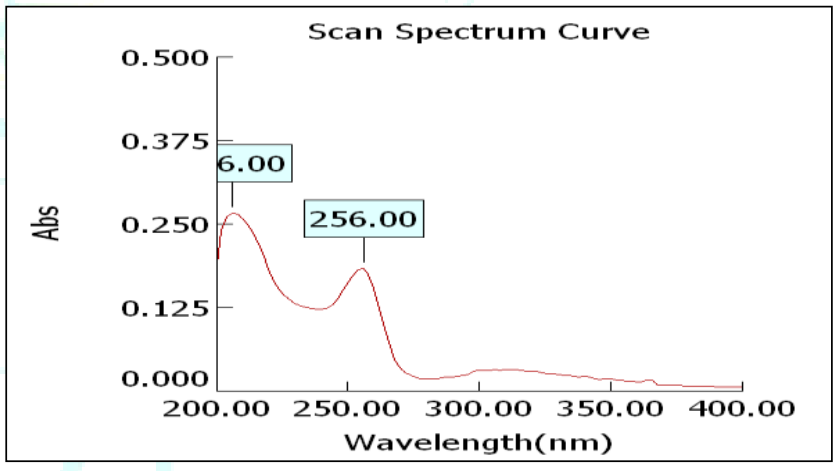

Figure 1 Determination of $\lambda_{\max }$ of PCZ

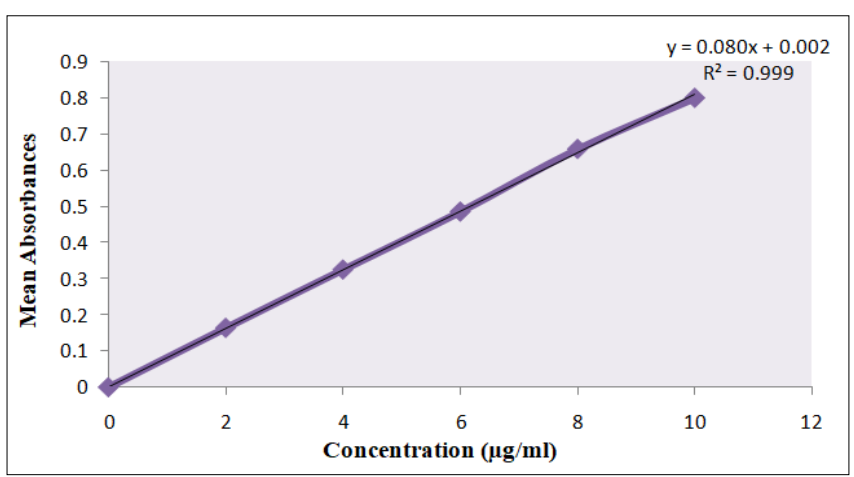

Figure 2 Calibration curve of PCZ at $256 \mathrm{~nm}$ 
Table 2 Results of pre-compression parameters of PCZ

\begin{tabular}{|c|c|c|c|c|}
\hline \multirow{2}{*}{$\begin{array}{c}\text { Formulation } \\
\text { code }\end{array}$} & \multicolumn{4}{|c|}{ Parameters } \\
\cline { 2 - 5 } & $\begin{array}{c}\text { Bulk } \\
\text { density(gm/ml) }\end{array}$ & $\begin{array}{c}\text { Tapped bulk } \\
\text { density(gm/ml) }\end{array}$ & $\begin{array}{c}\text { Carr's Index } \\
\text { (\%) }\end{array}$ & $\begin{array}{c}\text { Hausner's } \\
\text { Ratio }\end{array}$ \\
\hline F1 & 0.415 & 0.521 & 20.345 & 1.255 \\
\hline F2 & 0.426 & 0.529 & 19.471 & 1.242 \\
\hline F3 & 0.432 & 0.542 & 20.295 & 1.255 \\
\hline F4 & 0.436 & 0.541 & 19.409 & 1.241 \\
\hline F5 & 0.439 & 0.548 & 19.891 & 1.248 \\
\hline F6 & 0.438 & 0.542 & 19.188 & 1.237 \\
\hline
\end{tabular}

Table 3 Results of Post-Compression parameters of all formulations

\begin{tabular}{|c|c|c|c|c|c|c|}
\hline F. Code & $\begin{array}{l}\text { Hardness } \\
\left(\mathrm{kg} / \mathrm{cm}^{2}\right)^{*}\end{array}$ & $\begin{array}{c}\text { Friability } \\
(\%)^{*}\end{array}$ & $\begin{array}{c}\text { Weight } \\
\text { variation } \\
(\%)^{*}\end{array}$ & $\begin{array}{c}\text { Thickness } \\
\text { (mm)* }\end{array}$ & $\begin{array}{c}\text { Drug content } \\
(\%)^{*}\end{array}$ & $\begin{array}{c}\text { Disintegration } \\
\text { Time (sec.)* } \\
\text { Mean } \pm \text { SD }\end{array}$ \\
\hline F1 & $3.4 \pm 0.2$ & $0.856 \pm 0.045$ & $155 \pm 3$ & $2.2 \pm 0.2$ & $99.85 \pm 0.45$ & $120 \pm 5$ \\
\hline F2 & $3.5 \pm 0.3$ & $0.845 \pm 0.012$ & $154 \pm 4$ & $2.3 \pm 0.1$ & $99.65 \pm 0.25$ & $85 \pm 4$ \\
\hline F3 & $3.6 \pm 0.2$ & $0.658 \pm 0.25$ & $150 \pm 2$ & $2.4 \pm 0.3$ & $99.78 \pm 0.45$ & $110 \pm 2$ \\
\hline F4 & $3.5 \pm 0.1$ & $0.896 \pm 0.032$ & $148 \pm 5$ & $2.2 \pm 0.1$ & $99.45 \pm 0.65$ & $75 \pm 6$ \\
\hline F5 & $3.4 \pm 0.3$ & $0.754 \pm 0.054$ & $146 \pm 6$ & $2.5 \pm 0.4$ & $99.15 \pm 0.23$ & $65 \pm 5$ \\
\hline F6 & $3.5 \pm 0.4$ & $0.754 \pm 0.045$ & $153 \pm 4$ & $2.4 \pm 0.2$ & $99.12 \pm 0.41$ & $112 \pm 3$ \\
\hline
\end{tabular}

*Average of three determinations $(n=3)$

Table 4 In-vitro drug release data for optimized formulation F5

\begin{tabular}{|c|c|c|c|c|c|c|}
\hline $\begin{array}{c}\text { Time } \\
\text { (min) }\end{array}$ & $\begin{array}{c}\text { Square Root of } \\
\text { Time(h) }\end{array}$ & Log Time & $\begin{array}{c}\text { Cumulative*\% Drug } \\
\text { Release }\end{array}$ & $\begin{array}{c}\text { Log Cumulative } \\
\text { \% Drug Release }\end{array}$ & $\begin{array}{c}\text { Cumulative \% } \\
\text { Drug Remaining }\end{array}$ & $\begin{array}{c}\text { Log Cumulative } \\
\text { \% Drug } \\
\text { Remaining }\end{array}$ \\
\hline 2 & 1.414 & 0.301 & 48.85 & 1.689 & 51.15 & 1.7088 \\
\hline 5 & 2.236 & 0.699 & 75.65 & 1.879 & 24.35 & 1.3865 \\
\hline 10 & 3.162 & 1.000 & 98.89 & 1.995 & 1.11 & 0.0453 \\
\hline
\end{tabular}

Table 5 Regression analysis data

\begin{tabular}{|c|c|c|c|c|}
\hline \multirow{2}{*}{ Batch } & Zero Order & First Order & Higuchi & Korsmeyer-Peppas \\
\cline { 2 - 5 } & $\mathrm{R}^{2}$ & $\mathrm{R}^{2}$ & $\mathrm{R}^{2}$ & $\mathrm{R}^{2}$ \\
\hline F5 & 0.966 & 1.000 & 0.949 & 0.963 \\
\hline
\end{tabular}

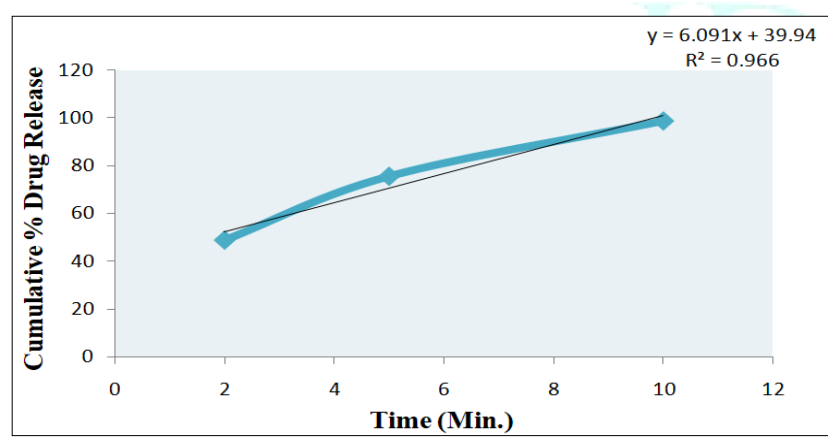

Figure 3 Zero order release Kinetics

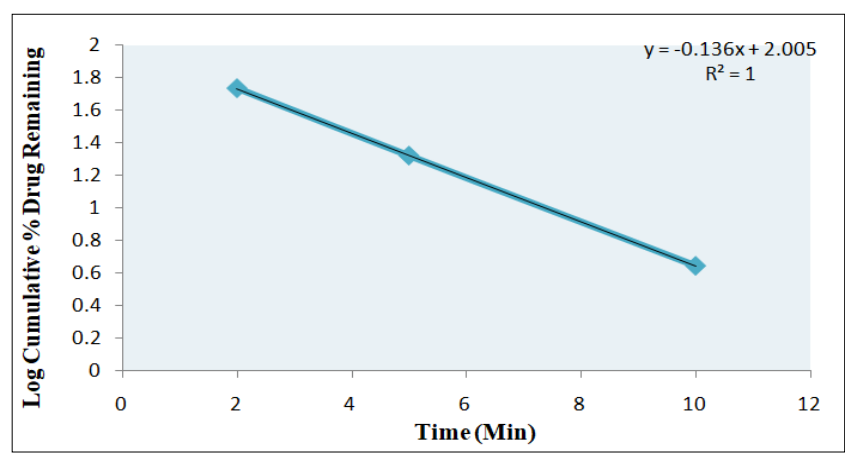

Figure 4 First order release kinetics

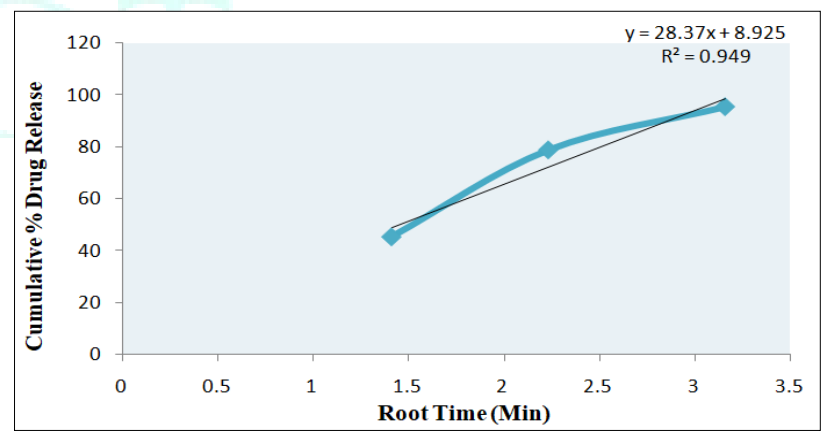

Figure 5 Higuchi release kinetics

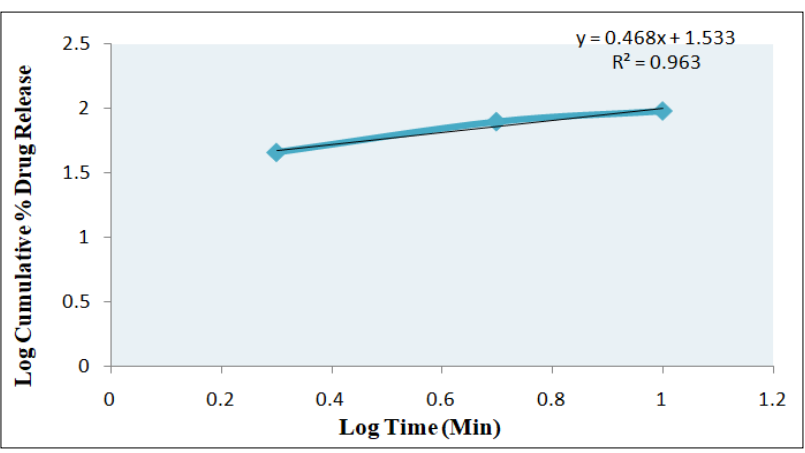

Figure 6 Korsmeyer-Peppas release kinetics 


\section{CONCLUSION}

The oral fast dissolving tablet of PCZ were formulated and evaluated for various parameters from the compatibility studies by IR of drug it was found to be compatible with other formulation excipients. All evaluation parameter were within specification. The crospovidone shown faster drug release than sodium starch glycolate and crosscarmellose sodium. Formulation F5 release maximum drug within the 10mins.ie. $98.89 \%$ and shown minimum disintegration time i.e. $65 \mathrm{sec}$ than other formulation and hence considered best formulation.

\section{REFERENCES}

1. Seager H. Drug delivery products and the Zydis Fast Dissolving Dosage Forms. J Pharm Pharmacol 1998;50:37582.

2. Chang RK, Guo X, Burnside BA, Cough RA. Fast dissolving tablets. Pharm Tech 2000;24:52-8.

3. Dobetti L. Fast-melting tablets: Developments and technologies. Pharma Tech 2001;(Suppl):44-50.

4. Kuchekar BS, Arumugam V. Fast dissolving tablets. Indian J Pharm Edu 2001;35:150-2.
5. Sweetman SC, editors. Martindale: The Complete Drug Reference. 33rd ed. London: Pharmaceutical Press, 2002. p.701.

6. Wilson CG, Washington N, Peach J, Murray GR, Kennerley J. The behaviour of a fast dissolving dosage form (expidet) followed by g-scintigraphy. Int J Pharm 1987;40:119-23.

7. Kuchekar BS, Badhan AC, Mahajan HS. Mouth dissolving tablets of salbutamol sulphate: A novel drug delivery system. Indian Drugs 2004;41:592-8.

8. Subramanyam CVS. Textbook of Physical Pharmaceutics. 3 rd ed. Vallabh Prakashan: Delhi (2001) 181-234.

9. T. Salsa, F. Veiga, M.E. Pina. Oral controlled-release dosage forms. i. cellulose ether polymers in hydrophilic matrices Drug Dev Ind Pharm. 1997; 23:929-938.

10. Mohd. Adil Khan, Girijesh Kumar Pandey, Amit Joshi, B.K Dubey, Amit Kumar Jain, Prabhat Jain. Formulation development and evaluation of fast dissolving oral film of a lipid-lowering drug. Asian Journal of Pharmaceutical Education and Research. 2019, Vol 8, Issue 1 (12-22)

11. Surya Prakash Gautam, Janki Prasad Rai, Uma Billshaiya, Nilesh Jain, Pradeep Vikram and Deepak Kumar Jain. Formulation and evaluation of mouth dissolving tablet of loperamide. International Journal of Pharmaceutical Sciences and Research 2013; Vol. 4(5): 1782-1788. 